\title{
WETENSCHAP
}

\section{De commanditaire matador revisited}

\section{Enkele opmerkingen over de interne en externe positie van commanditaire vennoten}

\section{J.B. Wezeman}

\section{$1 \quad$ Inleiding}

Personenvennootschappen - contractuele samenwerkingsverbanden in beroep en bedrijf - bezitten naar huidig recht geen rechtspersoonlijkheid. Zie recentelijk voor de vennootschap onder firma (vof) HR 19 april 2019 (UWV). ${ }^{1}$ Niettemin zijn personenvennootschappen in de praktijk populair. Deze populariteit heeft de personenvennootschap vooral te danken aan haar flexibele karakter. De vennoten zijn in hoge mate vrij hun onderlinge verhouding naar eigen goeddunken te regelen. Er zijn nauwelijks dwingende regels. Bij het handelsregister staan ruim 200.000 personenvennootschappen ingeschreven. Een klein deel daarvan zijn commanditaire vennootschappen (cv's). De laatste jaren wint de cv weer wat aan populariteit. Eind 2015 waren volgens de tellingssystematiek van het Centraal Bureau voor de Statistiek in alle economische branches 6600 cv's actief, eind 2020 was dit gestegen tot $7135 .{ }^{2}$ De cv wordt vooral gebruikt als ondernemingsvorm in het midden- en kleinbedrijf, als jointventuremaatschappij (bijvoorbeeld bij grote publiek-private samenwerkingsprojecten) en als beleggings- of investeringsfonds. ${ }^{3}$

Het beperkte gebruik van de cv houdt wellicht verband met de wat onduidelijke en van oudsher vrij strenge regel dat een commandiet op straffe van persoonlijke aansprakelijkheid geen daden van beheer mag verrichten of in de zaken van de vennootschap werkzaam mag zijn. Zie art. 20 lid 2 jo. art. 21 van het Wetboek van Koophandel (WvK). De onduidelijkheid betreft vooral de vraag welke gedragingen van de commandiet voor toepassing van deze bepaling als beheersdaad moeten worden aangemerkt. Een van de twistpunten daarbij is of het bij verboden beheersdaden alleen gaat om optreden waarvan naar buiten toe blijkt. Of strekt het be-

1 HR 19 april 2019, ECLI:NL:HR:2019:649, JOR 2019/173, m.nt. Faber; NJ 2019/438, m.nt. Verstijlen. Zie over dit arrest ook J.B. Huizink, In dienst van een vennootschap onder firma. Maar wat betekent dat nu helemaal?, TvI 2019/29.

2 Zie https://ondernemersplein.kvk.nl/de-commanditaire-vennootschap-cv. Zie ook https:// opendata.cbs.nl/statline/\#/CBS/nl/dataset/81588NED/table?ts=1617972381181. Het Ministerie van Justitie en Veiligheid schat het totaal aantal cv's gebaseerd op inschrijvingen bij de Kamer van Koophandel op circa 12.000 (zie MvT Consultatie-ontwerp Wet modernisering personenvennootschappen, p. 1 (noot 29)).

3 Vgl. A.J.S.M. Tervoort, Het bestuursverbod bij de commanditaire vennootschap (Uitgaven vanwege het Instituut voor Ondernemingsrecht, deel 93), Deventer: Kluwer 2013, p. 4-5. 
heersverbod zich ook uit - zonder dat dit voor derden kenbaar hoeft te zijn - tot vergaande beleidsbemoeienis van een commandiet binnen de vennootschap? Denk aan de situatie waarin de commandiet in feite 'de baas' is en de gang van zaken bepaalt. ${ }^{4}$

Het 'beheersverbod' (of 'bestuursverbod') staat de laatste jaren onder druk, zowel in de literatuur als in de rechtspraak. Een andere ontwikkeling vormt het voornemen van de Minister voor Rechtsbescherming om op korte termijn te komen tot een modernisering van het personenvennootschapsrecht. In de plannen van de minister wordt het beheersverbod afgeschaft en vervangen door een veel beperktere aansprakelijkheidsbepaling voor commanditaire vennoten. Voldoende aanleiding om in deze bijdrage opnieuw enige aandacht te schenken aan de rechtspositie van de commanditaire vennoot.

Hierna ga ik eerst kort in op de algemene positie van de commandiet in verhouding tot de vennootschap en de andere (gewone) vennoten (par. 2). Daarna komt de relatie van de commandiet tot de schuldeisers van de cv aan de orde (par. 3) en de positie van de commandiet die intern het beleid van de $\mathrm{cv}$ naar zijn hand zet (par. 4). Vervolgens bespreek ik de mitigering van de aansprakelijkheid van art. 21 WvK, zoals die in de rechtspraak van de laatste jaren tot stand is gekomen (par. 5). Paragraaf 6 is gewijd aan het vervallen van het beheersverbod in de wetgevingsplannen van de minister. Ik eindig met een aantal afsluitende opmerkingen (par. 7).

\section{De interne positie van de commandiet}

De cv wordt aangemerkt als een personenvennootschap zonder rechtspersoonlijkheid ter uitoefening van een bedrijf. Naast één of meer gewone vennoten heeft een $\mathrm{cv}$ ook één of meer commanditaire vennoten. De gewone vennoten van de cv zijn net als bij een vof naar huidig recht hoofdelijk aansprakelijk voor de verbintenissen van de vennootschap. De commanditaire vennoot echter is in beginsel in het geheel niet aansprakelijk voor de schulden van de cv. Dit beginsel lijdt uitzondering indien de commandiet daden van beheer verricht.

In zijn verhouding tot de vennootschap en de andere (gewone) vennoten heeft de commandiet een bijzondere positie die enigszins vergelijkbaar is met die van aandeelhouder in een nv of bv. De commandiet is net als de gewone vennoten gehouden iets in te brengen. De wet laat de vennoten een grote vrijheid bij het vormgeven van de inbreng. In de regel brengt een commandiet geld in. Ook kan hij zaken in eigendom inbrengen. Er ontstaat dan tussen de vennoten een gemeenschap als

4 In de literatuur bestaan hierover uiteenlopende opvattingen. Zie recentelijk J.E. van Nuland, Beleidsbepaling en aansprakelijkheid. Een drieluik over de feitelijke beheersing van vennootschappen (Serie vanwege het Van der Heijden Instituut, deel 170), Deventer: Wolters Kluwer 2020, p. 291 e.v. Zie uitvoerig ook Tervoort 2013 en A.J.S.M. Tervoort, Het Nederlandse personenvennootschapsrecht, Deventer: Wolters Kluwer 2015, die pleit voor afschaffing van het beheersverbod. Eerder betoogde ik dat de commandiet die binnen de cv de besluitvorming naar zijn hand zet het beheersverbod overtreedt. Zie J.B. Wezeman, De commanditaire matador en de nieuwe misbruikwetgeving, WPNR 1986, afl. 5802, p. 650 e.v. 
bedoeld in art. 3:166 van het Burgerlijk Wetboek (BW). Het bijzondere is nu dat een commandiet nooit tot meer is gehouden dan de overeengekomen inbreng. Zie art. 20 lid 3 WvK. Die bepaling moet zo worden verstaan dat de commandiet in zijn interne verhouding tot zijn medevennoten geen groter risico loopt voor zijn deelname aan de onderneming dan tot aan het bedrag van zijn kapitaalinbreng. Meer kan hij niet verliezen. Dit is een dwingende regel. Lijdt een cv verlies, dan kan een commandiet tegen zijn zin dus niet worden verplicht om dit verlies naar rato aan te zuiveren (bijvoorbeeld door een deel van zijn over eerdere jaren ontvangen winst te restitueren) of om zijn inbreng te verhogen. Deelt een commandiet zo beperkt in mogelijke verliezen, in gemaakte winsten kan hij wel volledig participeren. In beginsel deelt iedere vennoot - ook een commandiet - als deelnemer in de vennootschap naar rato van de waarde van zijn inbreng mee in gerealiseerde winsten. De vennoten kunnen echter in grote vrijheid andersluidende afspraken maken. Zo kan bij een cv zijn overeengekomen dat de commandiet jaarlijks in ieder geval een vaste rentevergoeding ontvangt over het door hem in de vennootschap gestoken kapitaal en in het dan nog resterende bedrijfsresultaat voor een bepaald percentage deelt. De jaarlijkse berekening van ieders winstaanspraak geschiedt in de regel op basis van de door alle vennoten gezamenlijk vastgestelde balans en winst-en-verliesrekening over het afgelopen boekjaar. Ook commanditaire vennoten worden bij die vaststelling betrokken. Een commandiet is immers méér dan een geldschieter, hij is als vennoot - binnen de grenzen gesteld in art. 20 lid 2 WvK (zie hierna par. 3 en 4) - in beginsel gerechtigd te participeren in de besluitvorming binnen de cv.

In HR 8 mei 1998 (Boterenbrood c.s./Mees Pierson)5 sprak de Hoge Raad zich uit over de vraag of een gewezen commanditaire vennoot jegens de cv nog draagplichtig is voor de ten tijde van zijn uittreding bestaande schulden van de vennootschap. Zonder veel omhaal van woorden besliste de Hoge Raad dat een commanditaire vennoot bij uittreding (en ook bij vereffening) aanspraak heeft op terugbetaling van zijn inbreng, in voorkomend geval verminderd met zijn aandeel in het verlies. Bij de berekening van het bedrag dat hem aldus toekomt, zal volgens de Hoge Raad rekening moeten zijn gehouden met de schuldenpositie van de vennootschap. Aangenomen moet worden dat met de terugbetaling de band tussen de uitgetreden commanditaire vennoot en de vennootschap volledig is geslaakt, dat het hem uitbetaalde niet door de vennootschap kan worden teruggevorderd, en dat hij ook niet (intern) jegens de vennootschap aansprakelijk is voor haar schulden. De Hoge Raad bevestigt in deze uitspraak dus allereerst dat de uittredende commanditaire vennoot alleen recht heeft op restitutie van zijn inbreng na verrekening met zijn aandeel in een eventueel verlies. Het belang van het arrest ligt vooral in de beslissing dat een met de uitgetreden commanditaire vennoot overeengekomen afrekening in beginsel definitief is. De Hoge Raad gaat er kortweg van uit dat bij de berekening van het bedrag waarop de uittredende commandiet recht heeft de 'schuldenpositie' van de vennootschap zal zijn verdisconteerd. Na ontvangst van dat bedrag kan de uitgetreden commandiet dan niet meer door de vennootschap

5 HR 8 mei 1998, ECLI:NL:HR:1998:ZC2646, NJ 1998/888, m.nt. Maeijer en Verkade; JOR 1998/110, m.nt. Grundmann-van de Krol en Goffen. Zie ook mijn bespreking van dit arrest in Dossier over Onderneming, Financiering en Recht 1998/34, p. 67-71. 
(of de andere vennoten) tot enige teruggave worden verplicht. Omgekeerd zal de uitgetreden commandiet later niets meer kunnen vorderen. Hoewel de Hoge Raad zich daar niet over uitspreekt, zal de ratio voor dit beginsel van eindafrekening liggen in de rechtszekerheid voor zowel de uittredende commandiet als de voortzettende vennoten.

Hoe nu om te gaan met gevallen waarin het verlies ten tijde van de uittreding van de commandiet nog niet (volledig) bekend was? Men denke aan een pas na uittreding bij de cv ingediende schadevergoedingsclaim op grond van art. 6:162 BW. Gaat het niet te ver om met een beroep op de rechtszekerheid aan te nemen dat de vennoten voor wat betreft hun onderlinge aanspraken ook met ieder latent verlies rekening zullen hebben gehouden? Ik neig ertoe deze vraag ontkennend te beantwoorden. De eindafrekeningsregel kan mede worden gezien als een redelijke toerekening van commerciële risico's, waarvan zowel uittredende commandieten als de overblijvende vennoten nu eens voordeel, dan eens nadeel kunnen ondervinden.

\section{De externe positie van de commandiet}

De goederen die in een maatschap, vof of $\mathrm{cv}$ door de vennoten zijn ingebracht en de goederen die de personenvennootschap tijdens haar bestaan verwerft, vallen in een gemeenschap in de zin van Boek 3, titel 7 BW. Deze gemeenschap vormt naar vaste jurisprudentie een zogenoemd 'afgescheiden vermogen'. Voor zaakschuldeisers van een cv betekent dit dat alleen zij zich op het vermogen van de cv kunnen verhalen, feitelijk met voorrang boven eventuele privéschuldeisers van de vennoten. Dit geldt zowel voor de cv met één als voor de cv met twee of meer beherende vennoten. ${ }^{6}$ De commanditaire inbreng nu dient ter verhoging van de kredietwaardigheid van de cv. Dit waarborgkarakter blijkt ook uit art. 17 van de Handelsregisterwet 2007 (Hregw 2007) jo. art. 18 Handelsregisterbesluit 2008: in het handelsregister moeten over een $\mathrm{cv}$ worden opgenomen het geldbedrag en de waarde van de goederen die de commanditaire vennoten gezamenlijk aan de cv ter beschikking hebben gesteld of overeengekomen zijn ter beschikking te zullen stellen. Een derde te goeder trouw mag erop vertrouwen dat deze vermelding van de commanditaire inbreng te allen tijde juist en volledig is. Veel zekerheid biedt deze inschrijving niet. Allereerst zijn er bij inbreng van zaken geen duidelijke regels hoe de waarde daarvan moet worden bepaald. De vennoten kunnen hier zelf afspraken over maken, waarbij als richtsnoer zal gelden een waardeberekening die in het maatschappelijk verkeer als aanvaardbaar wordt beschouwd. Belangrijker nog is dat het commanditaire kapitaal na inbreng door geleden verliezen kan zijn verdampt. De wet vereist alleen aanpassing van de inschrijving indien de totale commanditaire inbreng na oprichting van de $\mathrm{cv}$ wordt verhoogd of door terugbetaling van de inbreng of vermindering van de inbrengverplichting wordt verlaagd. ${ }^{7}$ Schending van deze ver- 
plichting vormt een economisch delict (art. 1 sub 4 van de Wet op de economische delicten (WED)). Civielrechtelijk zullen commandieten alleen risico lopen bij het niet inschrijven van een tussentijdse verlaging van het commanditaire kapitaal. Zo'n verlaging kan - indien aangetoond - in beginsel niet worden tegengeworpen aan de schuldeisers van de cv (art. 25 Hregw 2007).

Schuldeisers van een cv hebben over het algemeen geen goed inzicht in de financiele situatie van de cv. De vennootschap behoeft bijvoorbeeld geen jaarrekening vast te stellen of openbaar te maken, het bijzondere in art. 2:360 lid 2 BW genoemde geval daargelaten. Daar staat tegenover dat voor de verbintenissen van een $\mathrm{cv}$ net als bij een vof de gewone vennoten persoonlijk (en onderling hoofdelijk) aansprakelijk zijn. Zie art. 18 WvK. Deze bepaling geldt niet voor de commandiet. Commanditaire vennoten zijn in het geheel niet aansprakelijk voor de schulden van de cv. In beginsel zijn derden ook niet op de hoogte van de identiteit van de commandieten. In het handelsregister wordt wel hun aantal, maar niet hun naam ingeschreven (art. 17 Hregw 2007). In die zin worden commandieten ook wel 'stille' vennoten genoemd. Iets anders is dat een commandiet tegenwoordig wel met zijn naam geregistreerd kan staan in het bij de Kamer van Koophandel aangehouden UBO-register voor rechtspersonen en ondernemingen. Dit register is in Nederland ingevoerd op 27 september 2020, ter uitvoering van de vierde Europese anti-witwasrichtlijn. ${ }^{8}$ Om de transparantie van rechtspersonen en personenvennootschappen te bevorderen moet in het UBO-register iedere ultimate beneficial owner van de entiteit worden ingeschreven (art. 15a Hregw 2007). Met zo'n uiteindelijk belanghebbende wordt kort gezegd bedoeld de natuurlijke persoon die de uiteindelijke eigenaar is van of zeggenschap heeft over de betreffende entiteit. Bestaande rechtspersonen en personenvennootschappen hebben vanaf 27 september 2020 achttien maanden de tijd om al hun UBO's in te schrijven, dus tot 27 maart 2022. De UBO-registratie is deels openbaar. Tot de openbare informatie behoren de naam, geboortemaand en geboortejaar, woonstaat en nationaliteit van iedere UBO. Niet-openbare informatie (zoals adres en burgerservicenummer van een UBO) is uitsluitend in te zien door bevoegde autoriteiten, zoals het Openbaar Ministerie en opsporingsdiensten. Wie bij een personenvennootschap als UBO moeten worden aangemerkt, is bepaald in art. 3 lid 1 sub d Uitvoeringsbesluit Wwft 2018. ${ }^{9}$ Daaruit blijkt dat ook degene die direct of indirect (bijvoorbeeld via een bv) commanditaire vennoot is van een cv in een drietal gevallen als UBO moet worden geregistreerd, waaronder in de eerste plaats de situatie dat hij direct of indirect meer dan $25 \%$ van het eigendomsbelang in de cv houdt. Onder 'eigendomsbelang' is mede begrepen gerechtigdheid tot de winst van de vennootschap $!^{10}$

8 Zie hierover B. Snijder-Kuipers, UBO-registers in Nederland. It giet oan!, MvO 2020, p. 219-223.

9 Besluit van 25 juli 2018, Stb. 2018, 241 (gewijzigd bij besluit van 27 september 2020, Stb. 2020, 339 , ter uitvoering van de Wet ter voorkoming van witwassen en financieren van terrorisme (Wwft)).

10 Zie art. 3 lid 1 sub d jo. art. 1 Uitvoeringsbesluit Wwft 2018. UBO is daarnaast ook de commandiet die (2) direct of indirect meer dan $25 \%$ van de stemmen kan uitoefenen bij besluitvorming ter zake van wijziging van de cv-overeenkomst of ter zake van de uitvoering van die overeenkomst anders dan door daden van beheer, voor zover in die cv-overeenkomst besluitvorming bij meerderheid van stemmen is voorgeschreven, of (3) feitelijke zeggenschap over de cv kan uitoefenen. 
De commandiet betaalt wel een prijs voor zijn uitgesloten aansprakelijkheid jegens de schuldeisers van de cv. Op grond van art. 20 lid 2 WvK moet hij zich onthouden van iedere 'daad van beheer' en mag hij niet 'in de zaken van de vennootschap werkzaam zijn', zelfs niet uit kracht van een volmacht. Bovendien mag de naam van de commanditaire vennoot niet in de firma voorkomen (art. 20 lid 1 WvK). Overtreding van deze verboden leidt tot hoofdelijke aansprakelijkheid van de commanditair voor alle schulden en verbintenissen van de cv, ook voor zover deze verbintenissen al voor de overtreding van het verbod zijn ontstaan (art. $21 \mathrm{WvK}$ ). Ik merk nog op dat deze aansprakelijkheid alleen rust op degene die als rechtstreekse contractspartij van de andere vennoten formeel als commanditaire vennoot kan worden aangemerkt. Dat is met name relevant in situaties waarin de commanditaire positie wordt bekleed door een rechtspersoon. Is de commandiet bijvoorbeeld een bv, dan wordt de aansprakelijkheid van art. 21 WvK niet automatisch 'doorgeschoven' naar de bestuurders van die bv. Zij zijn immers geen vennoot. Een algemene met art. 2:11 BW vergelijkbare bepaling ontbreekt voor personenvennootschappen, afgezien van het voor fiscale schulden geldende art. 33 lid 3 Invorderingswet 1990. Is een schuldeiser van een cv gedupeerd door ongeoorloofd handelen van die bestuurders, dan zal hij voor mogelijke claims jegens die bestuurders aangewezen zijn op art. 6:162 BW of, bij faillissement van een krachtens art. 21 WvK aansprakelijke bv-vennoot, op een actie van de curator ex art. 2:248 BW.

\section{Het beheersverbod}

In de jurisprudentie wordt regelmatig met succes een beroep gedaan op het beheersverbod van art. 20 lid 2 WvK. Vaak gaat het daarbij om min of meer duidelijk liggende gevallen. Zo zal bijvoorbeeld de commandiet die namens de cv zijn bank opdraagt een schuld van de cv te betalen een daad van beheer als bedoeld in art. 20 WvK verrichten. ${ }^{11}$ Fout zit ook de commandiet die, al is het in het kader van beëindiging van een $\mathrm{cv}$, namens de $\mathrm{cv}$ met de schuldeisers gaat corresponderen om tot een betalingsregeling te komen. ${ }^{12}$ Toch roept het streng geformuleerde beheersverbod ook de nodige vragen op. In de literatuur is daaraan ruime aandacht besteed. ${ }^{13}$ Een betwiste vraag bij de toepassing van het beheersverbod van art. 20 lid 3 WvK is of de aansprakelijkheid wegens overtreding van het beheersverbod alleen kan intreden indien daarvan naar buiten toe blijkt. De Hoge Raad heeft deze vraag nog nooit beantwoord. In de literatuur zijn ruwweg twee opvattingen te onderscheiden. In de ene opvatting kan de aansprakelijkheid van art. 21 WvK kort gezegd pas intreden indien de commandiet extern blijkende beheersdaden verricht die bij derden de indruk kunnen wekken dat hij een gewone, hoofdelijk aansprakelijke vennoot is. ${ }^{14}$ Daartegenover staat de opvatting die een wat ruimere uitleg aan het be-

11 Zie HR 24 april 1970, ECLI:NL:HR:1970:AC5021, NJ 1970/406, m.nt. GJS (Romano import).

12 Zie Hof Arnhem 21 juli 2009, ECLI:NL:GHARN:2009:BK8091, JOR 2010/37, m.nt. Stokkermans (Sport Shop Actief).

13 Zie voor recente literatuur noot 4.

14 Zie voor deze opvatting o.a. V.A.E.M. Meijers, Mohr. Van personenvennootschappen, Deventer: Wolters Kluwer 2018, par. 4.1 (p. 95-96). 
heersverbod wil geven en daaronder ook laat vallen een zodanige interne bemoeienis van de commandiet met het beleid van de cv, dat hij de gang van zaken binnen de cv volledig of grotendeels naar zijn hand zet. ${ }^{15}$

Zonder hier uitgebreide discussies met argumenten pro en contra te herhalen houd ik het erop dat deze laatste, ruimere uitleg van het beheersverbod de sterkste kaarten heeft en geen onredelijk aansprakelijkheidsrisico bij de commandiet neerlegt. Verdedigbaar is dat het beheersverbod niet alleen de schuldeisers van de cv wil beschermen, maar dat het ook de gewone vennoten beschermt tegen een commandiet die - zonder risico voor eigen aansprakelijkheid - in vennootschapszaken zijn wil aan hen tracht op te leggen. ${ }^{16}$ Ook de tekst van art. 20 lid 3 WvK dwingt niet tot een beperking tot uitsluitend extern handelen. Wie toch vast wil houden aan naar buiten blijkende beheersdaden moet zich realiseren dat een scherp onderscheid niet altijd valt te maken. Vaak zullen aan een intern te overheersend optreden van de commandiet immers ook extern werkzame gevolgen verbonden zijn. Het verbieden van overheersende interne invloed van commandieten dient daarom ook het belang van de zaaksschuldeisers. Overigens rust de bewijslast van het overtreden van het beheersverbod in beginsel uiteraard op de schuldeiser van de cv die art. 21 WvK inroept.

De ruimere uitleg van het beheersverbod van art. 20 WvK gaat niet zover dat iedere interne bemoeienis van de commandiet met het beleid van de $\mathrm{cv}$ uit den boze zou zijn. De commanditair is méér dan een geldschieter, hij is vennoot. Die positie brengt mee dat hij zich tot op zekere hoogte wel degelijk met de zaken van de cv mag inlaten en de gewone vennoten ook kan verplichten rekening en verantwoording af te leggen over het gevoerde beleid. De Hoge Raad bevestigde dit in 2017 nog in een korte algemene overweging in het arrest Bastion de Leede. ${ }^{17}$ In deze zaak ging het om een mislukt onroerend project, uitgevoerd door een $\mathrm{cv}$ met één beherend vennoot en een aantal commandieten ('participanten'). Inzet van het geschil was de vraag of een advocaat die de - later gefailleerde - cv ter zake van het project had geadviseerd zijn taak onjuist had vervuld. De Hoge Raad overweegt dat een redelijk handelend en redelijk bekwaam advocaat die een $\mathrm{cv}$ adviseert, zich dient te richten op het belang van de $\mathrm{cv}$, dat niet alleen bestaat in het belang van de beherende vennoten, maar ook in het gezamenlijke belang van de beherende en de commanditaire vennoten. In een korte, algemene onderbouwing van die beslissing voert de Hoge Raad aan dat een cv een samenwerkingsverband is van personen, en ook dat de strekking van de verboden van art. 20 lid 2 WvK niet eraan in de weg staat 'dat de vennootschapsovereenkomst de commanditaire vennoten bepaalde (interne) zeggenschapsrechten toekent' (r.o. 3.5.2-3.5.4) ${ }^{18}$ De commandiet zal zich dus wel mogen bemoeien met het intern uitstippelen van het beleid van de cv. Het samenwerkingskarakter van de personenvennootschap brengt dat mee. Het

15 Zie voor deze opvatting o.a. Asser/Maeijer \& Van Olffen 7-VII 2017/371.

16 Zie mijn in noot 4 genoemde WPNR-bijdrage uit 1986, met name p. 655 en de daar vermelde literatuur. Zie ook Van Nuland 2020, par. 6.3.2.

17 HR 22 september 2017, ECLI:NL:HR:2017:2444, NJ 2017/395, m.nt. P. van Schilfgaarde; JOR 2017/285, m.nt. Blanco Fernández.

18 Evenzo A-G Timmerman in zijn conclusie voor dit arrest, nr. 3.5. 
verbod van art. 20 lid 2 WvK staat er niet aan in de weg dat de commanditair toezicht uitoefent op de besluitvorming binnen de vennootschap, de beherende vennoten ter zake van advies dient of ook aan de besluitvorming deelneemt. ${ }^{19}$ Ook kan de commandiet voor bepaalde besluiten een goedkeurings- of vetorecht worden toegekend.

In mijn WPNR-artikel uit 1986 maakte ik een vergelijking tussen de aansprakelijkheid van de commandiet wegens overtreding van het beheersverbod en de aansprakelijkheid van (mede)beleidsbepalers van nv's en bv's als bedoeld in het zevende lid van het op 1 januari 1987 ingevoerde art. 2:138/248 BW. Die beleidsbepaler, schreef ik in 1986, is de matador, degene die door zijn macht, geld of bekwaamheid het spel binnen de nv of bv domineert. Terecht biedt art. 2:138/248 lid 7 BW de mogelijkheid om in geval van tot faillissement leidend kennelijk onbehoorlijk bestuur naast de formele bestuurders ook eenieder die zich in feite als bestuurder heeft gedragen aansprakelijk te houden. De bestuurdersaansprakelijkheid van art. 2:138/248 BW zou anders eenvoudig kunnen worden ontgaan. Betoogd kan worden dat art. 2:138/248 lid 7 BW en art. 20 lid 3 WvK beide beogen misbruiksituaties te voorkomen. De (mede)beleidsbepaler bij de nv/bv kan intussen niet op één lijn worden gesteld met de commandiet die het bestuursverbod overtreedt in de hiervoor beschreven zin. Uit de jurisprudentie sinds 1987 blijkt dat voor toepassing van art. 2:138/248 lid 7 BW een daadwerkelijke, actieve bemoeienis met het bestuur is vereist, al dan niet met terzijdestelling van de formele bestuurders. ${ }^{20}$ Daaruit spreekt een bredere benadering. Niet steeds vereist is dus dat de (mede)beleidsbepaler rechtstreeks zijn wil heeft opgelegd aan de formele bestuurders. ${ }^{21}$

\section{$5 \quad$ Mitigering van aansprakelijkheid}

De Hoge Raad heeft in een uitspraak van 29 mei 2015 de aansprakelijkheid van art. $21 \mathrm{WvK}$ in verbinding met de verboden van art. $20 \mathrm{WvK}$ aanzienlijk verzacht. ${ }^{22}$ In dit Lunchroom De Katterug-arrest brengt de Hoge Raad belangrijke nuanceringen aan op de - tot dan toe - onverbiddelijk streng toegepaste 'sanctie' van art. 21 WvK. In afwijking van oudere rechtspraak overweegt de Hoge Raad dat de aansprakelijkheid van art. $21 \mathrm{WvK}$ uitsluitend gerechtvaardigd is indien en voor zover zij in overeenstemming is met de strekking ervan, te weten het voorkomen dat commanditaire vennoten die op een van de in art. 20 WvK vermelde manieren ondui-

19 Terughoudender: Van Nuland 2020, par. 6.2.2. Ik wijs nog op een bijzondere uitzondering in art. 32 WvK. Dit artikel bepaalt dat een commandiet bij ontbinding niet mag meestemmen over de benoeming van een vereffenaar. In de literatuur wordt aangenomen dat de commandiet ook niet zelf als vereffenaar mag optreden. Vgl. Tervoort 2015, p. 228.

20 Zie recentelijk Hof 's-Hertogenbosch 28 januari 2020, ECLI:NL:GHSHE:2020:256, JOR 2021/2. Zie over art. 2:138/248 lid 7 BW verder J.N. Schutte-Veenstra, Formeel of feitelijk bestuurder; makkt het verschil?, in: G. van Solinge e.a. (red.), Aansprakelijkheid van bestuurders en commissarissen (Serie vanwege het Van der Heijden Instituut, deel 140), Deventer: Wolters Kluwer 2017, p. 129-156.

21 Zie over de verschillen van beide figuren ook Van Nuland 2020, par. 6.5.

22 HR 29 mei 2015, ECLI:NL:HR:2015:1413, NJ 2015/380, m.nt. P. van Schilfgaarde; JOR 2015/192, m.nt. Stokkermans. 
delijkheid laten ontstaan over hun rechtspositie in de vennootschap, zich kunnen onttrekken aan de aansprakelijkheid die art. 18 WvK voorziet voor de gewone vennoten. De aansprakelijkheidssanctie mag volgens de Hoge Raad dan ook 'niet in een onevenredige verhouding staan tot de aard en ernst' van de schending door de commanditaire vennoot van de verboden van art. $20 \mathrm{WvK}$. De aansprakelijkheid van art. 21 WvK dient achterwege te blijven 'indien en voor zover zij door het handelen van de commanditaire vennoot niet of niet ten volle wordt gerechtvaardigd' (zie r.o. 3.4.4). Bij de beantwoording van de vraag of en in hoeverre plaats is voor het intreden van de aansprakelijkheid van art. $21 \mathrm{WvK}$ kan mede van belang zijn, aldus de Hoge Raad, of derden van de vennootschappelijke hoedanigheid van de commanditaire vennoot op de hoogte waren of behoorden te zijn (r.o. 3.4.5). Vereist is in elk geval steeds, zo overweegt de Hoge Raad in r.o. 3.4.6, dat de commanditaire vennoot tegen wie art. $21 \mathrm{WvK}$ wordt ingeroepen van zijn handelen enig verwijt valt te maken. ${ }^{23}$ In de onderhavige zaak - waarin de commandieten naast de beherende vennoot namens de $\mathrm{cv}$ een huurovereenkomst hadden ondertekend zonder dat de $\mathrm{cv}$, de beherende vennoot of de verhuurder (die van ieders hoedanigheid op de hoogte was) daardoor op enige wijze werd benadeeld - stuitte de aansprakelijkheid van de commandieten daarop naar mijn mening terecht af.

De Hoge Raad heeft de in het Lunchroom De Katterug-arrest geformuleerde mitigeringsregel later herhaald in HR 4 november 2016 (Distriport) ${ }^{24}$ Ook uit de lagere jurisprudentie zijn inmiddels enkele voorbeelden van toepassing van deze verzachting bekend. ${ }^{25}$ In het Distriport-arrest besliste de Hoge Raad verder dat, behoudens tegenbewijs, een persoon die zowel een beherend als een commanditaire vennoot kan vertegenwoordigen, bij het verrichten van een beheershandeling geacht wordt te hebben gehandeld namens de beherend vennoot. Ook deze laatste beslissing biedt commandieten iets meer speelruimte en is voor de praktijk van groot belang. Het komt wel voor dat de beherend en de commanditaire vennoot van een cv beide bv's zijn die (direct of indirect) dezelfde bestuurder hebben. Omdat de beherende en commanditaire vennoot dan per saldo te herleiden zijn tot één en dezelfde persoon aan wiens ondeelbare brein het beleid van de $\mathrm{cv}$ volledig ontspruit, zou aansprakelijkheid van art. $21 \mathrm{WvK}$ dan steeds zijn gegeven. Het Distriport-arrest lijkt mij een belangrijke aanwijzing dat in de ogen van de Hoge Raad bij dergelijke bv/ cv-constructies de enkele dubbelrol van de betreffende bestuurder niet voldoende is om de voor toepassing van art. $21 \mathrm{WvK}$ vereiste verwijtbaarheid aan te nemen. ${ }^{26}$

23 Zie hierover uitvoerig Van Nuland 2020, par. 6.4.2.

24 HR 4 november 2016, ECLI:NL:HR:2016:2516, NJ 2017/61, m.nt. P. van Schilfgaarde; JOR 2016/326, m.nt. Blanco Fernández. Zie voor het vervolg van deze zaak Hof Den Haag 18 december 2018, ECLI:NL:GHDHA:2018:3706, JOR 2019/54.

25 Zie o.a. Hof Arnhem-Leeuwarden 12 mei 2020, ECLI:NL:GHARL:2020:3677, JOR 2020/199, m.nt. A.J.S.M. Tervoort (De Sjalon).

26 Terughoudender: W.R. Kooiman \& F.M. Witpeerd, Anonimisering door de CV: een leeuwenvennootschap, WFR 2018/78. 


\section{Modernisering personenvennootschapsrecht}

De wetgeving voor personenvennootschappen dateert uit 1838. Nadien is het personenvennootschapsrecht slechts op kleine onderdelen gewijzigd. De gedateerde regeling van de personenvennootschappen is daarnaast verspreid over het BW en het WvK. De maatschap is geregeld in art. 7A:1655-1688 BW, de vof en $\mathrm{cv}$ in art. 15-34 WvK. Lange tijd wordt al gesproken over vernieuwing van deze wettelijke regels en over het samenbrengen van de verschillende personenvennootschappen in Boek 7 BW. Tien jaar geleden werden twee daartoe strekkende wetsontwerpen tegen het einde van de parlementaire behandeling door de Minister van Veiligheid en Justitie in 2011 onverwacht ingetrokken. ${ }^{27}$ Inmiddels staat de modernisering van het personenvennootschapsrecht weer op de wetgevingsagenda. Medio 2016 presenteerde een breed samengestelde werkgroep met leden afkomstig uit praktijk en wetenschap een nieuw conceptwetsvoorstel. Eind 2016 gaf de Minister van Veiligheid en Justitie te kennen op dit voorstel te willen voortbouwen. ${ }^{28}$ Inmiddels heeft begin 2019 de Minister voor Rechtsbescherming aangekondigd de personenvennootschappen inderdaad van een modern wettelijk kader te willen voorzien in een nieuwe titel 13 ('Vennootschap') van Boek 7 BW. De minister heeft in februari 2019 een zogeheten consultatievoorstel met toelichting voor een Wet modernisering personenvennootschappen openbaar gemaakt. ${ }^{29}$ De nieuwe regeling zal leiden tot een aantal belangrijke veranderingen. Zo introduceert het voorontwerp rechtspersoonlijkheid voor de personenvennootschap. Het gaat hier om een bijzondere rechtspersoonlijkheid: de vennoten blijven persoonlijk aansprakelijk voor de verbintenissen van de personenvennootschap-rechtspersoon en de bepalingen van Boek 2 BW zijn (met uitzondering van art. 4 lid 2 en art. 5) niet van toepassing. Verder worden de vertegenwoordigingsregels voor alle personenvennootschappen geüniformeerd. Het consultatieontwerp verklaart anders dan onder het huidige recht in beginsel iedere vennoot bevoegd de personenvennootschap te vertegenwoordigen, zowel bij bedrijfs- als bij beroepsuitoefening. In het verlengde hiervan wordt bij elke personenvennootschap hoofdelijke verbondenheid voor de verbintenissen van de personenvennootschap uitgangspunt, voor zover de wederpartij aannemelijk maakt dat de vennootschap zelf de verbintenis niet zal voldoen. Het is nog niet bekend wanneer een wetsvoorstel bij de Tweede Kamer zal worden ingediend en op welke termijn invoering daarvan te verwachten is. Mogelijk volgt in 2021 nog een tweede consultatieronde, gelet op de uitvoerige reacties op de eerste consultatie.

In het consultatiewetsvoorstel houden vennoten van personenvennootschappen een grote mate van vrijheid de interne organisatie van personenvennootschappen vorm te geven. Zie ontwerp-art. 7:804 BW. Deze bepaling bevat regels over bestuursbevoegdheid (in het huidige recht: beheersbevoegdheid). De vennoten be-

28 Zie hierover H.E. Boschma \& J.B. Wezeman, De personenvennootschap op weg naar 2020, AA 2017, afl. 3, p. 203-214. Enkele in deze paragraaf opgenomen passages zijn ontleend aan dat artikel.

Zie www.internetconsultatie.nl. Het voorstel is te vinden onder het kopje 'Gesloten consultaties'. 
sturen gezamenlijk. Dit geldt voor iedere personenvennootschap. Het consultatiewetsvoorstel laat net als het huidige recht in het midden wat onder besturen dient te worden verstaan. Dat is niet zo bezwaarlijk, nu wel uitdrukkelijk is geregeld dat iedere gewone vennoot individueel bevoegd is voor rekening van de vennootschap alle handelingen te verrichten die gelet op het doel van de vennootschap tot haar normale werkzaamheden behoren, alsmede handelingen die geen uitstel kunnen lijden. Andere handelingen mogen dus slechts krachtens unaniem (vooraf of achteraf) genomen besluit van de vennoten worden verricht. Bij of krachtens de vennootschapsovereenkomst kan anders zijn bepaald. Zo kan - net als onder het huidige recht - het bestuur van de vennootschap geheel of gedeeltelijk worden opgedragen aan één of meer derden (niet-vennoten). Ook kan een vennoot van het bestuur worden uitgesloten of kan de bestuursbevoegdheid van een vennoot aan voorwaarden worden verbonden. Een van de belangrijkste bestuurstaken van vennoten is het namens de vennootschap verrichten van rechtshandelingen met een derde, waardoor de vennootschap jegens die derde wordt verbonden. Art. 7:808 BW van het consultatiewetsvoorstel bepaalt dat iedere vennoot bevoegd is de vennootschap (vof of maatschap) te vertegenwoordigen.

Het consultatiewetsvoorstel wijdt slechts drie bepalingen aan de cv. Zie ontwerp-art. 7:820, 821 en 822 BW. De wetgever kan met een beperkte regeling volstaan, omdat de $\mathrm{cv}$ een bijzondere vorm is van de gewone vennootschap en alleen de afwijkende aspecten behoeven te worden geregeld. Het voorstel handhaaft de hoofdregel dat commanditaire vennoten niet persoonlijk verbonden zijn voor de schulden van de vennootschap (ontwerp-art. 7:820 BW) en dat zij niet verder bijdragen in de verliezen dan tot het bedrag van de overeengekomen inbreng (ontwerp-art. 7:821 lid $1 \mathrm{BW}$ ). De keerzijde hiervan is dat de commandiet dwingend is uitgesloten van de wel aan iedere gewone vennoot toekomende algemene bevoegdheid de vennootschap te vertegenwoordigen. Volgens de ontwerp-memorie van toelichting is dat ook 'logisch, om de vennoten en de schuldeisers niet te benadelen als de commanditaire vennoot geheel niet kan worden aangesproken'. ${ }^{30}$

Het beheersverbod en ook het naamvoeringsverbod van art. 20 WvK keren echter niet terug in het consultatiewetsvoorstel. De minister acht deze verboden 'niet langer van deze tijd' en te inflexibel. ${ }^{31}$ Deze verboden zullen daarom vervallen. De minister wil de commanditaire vennoten meer ruimte bieden voor betrokkenheid bij de dagelijkse bedrijfsvoering. ${ }^{32}$ De minister wil zelfs toestaan dat de commandiet met incidentele of doorlopende volmacht van de gewone vennoten de cv vertegenwoordigt en dan dus namens de $\mathrm{cv}$ aan het rechtsverkeer deelneemt (ontwerp-art. 7:821 lid 2 BW). Overigens merkt de minister met verwijzing naar het Bastion de Leede-arrest (zie par. 4) op dat ook naar huidig recht een commanditaire vennoot op basis van de vennootschapsovereenkomst invloed of inspraak mag hebben bij de besluitvorming binnen de vennootschap. ${ }^{33}$ Gelet op het regelende 
karakter van de bestuursregels in ontwerp-art. 7:804 BW zou het bestuur van de cv in de toekomst mijns inziens desgewenst zelfs exclusief aan een (gevolmachtigde) commandiet kunnen worden toebedeeld.

De commanditaire vennoot zal onder de nieuwe regels wel enig aansprakelijkheidsrisico lopen. Om misbruik van de nieuwe vrijheden te voorkomen, bepaalt ontwerp-art. 7:821 lid 3 BW naar voorbeeld van art. 2:138/248 BW dwingend dat de commanditaire vennoot jegens de boedel hoofdelijk aansprakelijk is voor het boedeltekort indien zijn handelen krachtens volmacht een belangrijke oorzaak is van het faillissement van de cv. De rechter kan deze aansprakelijkheid zo nodig matigen, gelet op de aard en ernst van het handelen door de commanditaire vennoot, de andere oorzaken van het faillissement, alsmede de wijze waarop dit is afgewikkeld (ontwerp-art. 7:821 lid 4 BW). Ook de formulering van deze matigingsbevoegdheid lijkt ontleend aan art. 2:138/248 BW. In dat licht zou ik aan willen nemen dat de aansprakelijkheid van de krachtens volmacht handelende commandiet alleen aan de orde is indien hem een verwijt van kennelijk onbehoorlijk handelen kan worden gemaakt. Opvallend is dat de aansprakelijkheid van ontwerp-art. 7:821 BW alleen kan intreden bij handelen 'krachtens volmacht'. Goed voorstelbaar is dat ook ander - feitelijk - handelen van de commandiet het faillissement van de cv kan hebben veroorzaakt. Aansprakelijkheid van de commandiet jegens derden kan in de systematiek van het consultatiewetsvoorstel uit 2019 dan alleen worden gebaseerd op art. 6:162 BW. In lijn weer met het voor bestuurders van nv's en bv's in art. 2:138/248 BW bepaalde zou de regel van ontwerp-art. 7:821 lid 2 BW zich wat mij betreft ook moeten uitstrekken tot alle gevallen van kennelijk onbehoorlijk optreden van de commandiet dat een belangrijke oorzaak is geweest van het faillissement van de $\mathrm{cv}^{34}$

\section{Besluit}

Het personenvennootschapsrecht is in beweging. Dat geldt zeker voor commanditaire vennootschappen. Door de arresten Lunchroom De Katterug, Distriport en Bastion de Leede is de rechtspositie van commanditaire vennoten verduidelijkt en verbeterd. De twee laatstgenoemde arresten uit 2016 en 2017 werpen meer licht op de contouren van het voor de commandiet geldende beheersverbod van art. 20 lid $2 \mathrm{WvK}$. Enige invloed binnen de $\mathrm{cv}$ is hem in beginsel toegestaan, ook bij bv/ $\mathrm{CV}$-constructies waarbij de commandiet een zekere dubbelrol heeft. Wel handelt mijns inziens de commandiet die binnen de cv overheersende invloed uitoefent en de gewone vennoten in feite ter zijde stelt in strijd met het beheersverbod. Met als consequentie dat de commandiet hoofdelijk aansprakelijk is voor alle schulden van de cv (art. 21 WvK). Het arrest Lunchroom De Katterug uit 2015 leidt daarbij tot een belangrijke mitigering. Onbeperkte hoofdelijke aansprakelijkheid van de commandiet is alleen aan de orde indien de omvang en ernst van de overtreding van het beheersverbod dit rechtvaardigen. De komende jaren moet blijken hoe ruim-

34 Evenzo Chr.M. Stokkermans, Sleutels voor personenvennootschapsrecht, Deventer Wolters Kluwer 2017, p. 315. 
hartig deze - terechte - verzachting in de praktijk wordt ingevuld. Een andere ontwikkeling is het voornemen van het kabinet om de wettelijke regels voor personenvennootschappen te moderniseren. Overwogen wordt, in navolging van pleidooien in de literatuur, het beheersverbod voor commanditaire vennoten geheel te schrappen en te vervangen door een (zeer) beperkte aansprakelijkheidsbepaling bij faillissement van de cv. 